\title{
SISTEM PENDUKUNG KEPUTUSAN PENILAIAN KINERJA DOKTER MENGGUNAKAN METODE WEIGHT PRODUCT (WP) BERBASIS WEB
}

\author{
Dira Junifa, *Siti Aisyah, Angelina Cikita Mutiara Br Simanjuntak, Syahril Ginting \\ Program Studi Sistem Informasi Fakultas Teknologi dan Ilmu Komputer Universitas Prima Indonesia \\ E-mail : *sitiaisyah@unprimdn.ac.id
}

\begin{abstract}
ABSTRAK- Dokter adalah seseorang yang karena pengetahuannya berusaha menyembuhkan orang yang sakit. Dokter harus memiliki profesionalisme dan kualitas dalam memberikan layanan kesehatan yang berkualitas. Salah satu upaya untuk memacu kinerja dokter dengan melakukan evaluasi kinerja guna meningkatkan semangat kinerja dan prestasi. Saat ini sistem evaluasi pekerjaan di Rumah Sakit Royal Prima Medan masih dilakukan secara konvensional dan hasil penilaian bersifat subyektif. Berdasarkan hal ini, penulis merancang Sistem Pendukung Keputusan untuk Mengevaluasi Kinerja Dokter menggunakan WEB-based Weighted Product (WP). Ada lima kriteria dalam mengevaluasi kinerja dokter termasuk penilaian perawatan pasien, keterampilan interpersonal dan komunikasi, penulisan dan kelengkapan catatan medis, profesionalisme / perilaku kerja. Penelitian dilakukan dengan mencari nilai bobot kriteria dan kemudian memproses peringkat dari penilaian dokter.
\end{abstract}

\section{Keywords: Sistem Pendukung Keputusan, Weight Product, WEB}

\section{PENDAHULUAN}

Dokter adalah seseorang yang karena keilmuannya berusaha menyembuhkan orang-orang yang sakit. Untuk menjadi dokter biasanya diperlukan pendidikan dan pelatihan khusus dan mempunyai gelar dalam bidang kedokteran. Upaya yang dilakukan untuk meningkatkan semangat kinerja yang lebih baik dan berprestasi, sebuah institusi memberikan penghargaan kepada dokter yang dianggap berprestasi. Penghargaan yang diberikan bisa berupa plakat, kenaikan jabatan, golongan dan lainnya. Penghargaan ini dapat memicu semangat dalam bekerjadan memberikan pelayanan kesehatan dengan baik.

Salah satu teknologi informasi yang digunakan pada bidang kesehatan adalah Sistem Pendukung Keputusan (SPK) yang digunakan untuk membantu pengambilan keputusan berdasarkan kriteria yang sudah ditentukan. Penelitian yang dilakukan dalam Sistem pendukung keputusan diantaranya adalah Analisis Dan Perancangan Sistem Pendukung Keputusan Penilaian Kinerja Guru Dengan Menggunakan Metode Simple Additive Weighting (Saw) Pada SMK Yadika Jambi oleh Nana Yulia Fitri (2017), Sistem Pendukung Keputusan Untuk Penentuan Mahasiswa Berprestasi Menggunakan Weighted Product (WP) oleh Muhammad Mukmin (2018), Implementasi Metode TOPSIS Dalam Sistem Pendukung Keputusan Seleksi Penerima Beasiswa Bidikmisi Berbasis Web oleh Tri Widayanti (2016).

Rumah sakit Royal Prima Medan adalah salah satu rumah sakit yang menjadi pusat pelayanan kesehatan di kota Medan. Dokter yang bertugas pada rumah sakit ini terdiri dari dokter umum, dokter spesialis dan dokter gigi, poliklinik rehabilitas medik. Dalam menentukan penilaian kinerja para dokter para jajaran pemimpin masih menggunakan cara konvensional. Penilaian masih dilakukan secara manual dan proses pengolahan datanya belum menggunakan program aplikasi dalam mengambil keputusan. Salah satu alternatif untuk menghindari penilaian yang bersifat subyektif tersebut adalah dengan menggunakan model penentuan prestasi kinerja dokter berdasarkan kriteria yang ditetapkan oleh jajaran pimpinan rumah sakit.

Berdasarkan permasalahan diatas, maka dirancang sistem yang dapat menghitung serta membantu menyelesaian dengan perhitungan menggunakan perkalian untuk menghubungkan rating atribut, dimana rating harus dipangkatkan terlebih dahulu dengan bobot atribut yang bersangkutan. Diharapkan sistem ini dapat membantu pengambil keputusan dalam mendapatkan informasi untuk menentukan prestasi kinerja dokter yang bersifat lebih obyektif.

\section{METODE PENELITIAN}

\section{1 Pengumpulan Data}

Pengumpulan data yang dilakukan penulis dengan melakukan pengambilan data melalui metode penelitian sebagai berikut :

1. Pengamatan (Observasi) yaitu teknik pengumpulan data yang dilakukan dengan cara mengadakan pengamatan secara langsung pada obyek penelitian yang merupakan sumber data baik secara fisik (alat-alat yang dipakai) maupun konsep (cara kerja dari alat-alat yang dipakai), dalam hal ini observasi dilaksanakan di RS Royal Prima. 
2. Library Research yaitu teknik pengumpulan data dengan mencari, membaca, mencatat dan mengumpulkan bahan-bahan dari literatur yang terdapat dalam perpustakaan, media cetak, internet serta data-data lainya yang relevan media dengan masalah yang di teliti.

3. Sampling, yaitu teknik pengumpulan data yang dilakukan dengan cara melakukan pengambilan data arsip/formulir/catatan yang berkaitan dengan obyek penelitian.

\subsection{Sistem Pendukung Keputusan}

Sistem Pendukung Keputusan (SPK) atau Decision Support System (DSS) adalah sebuah sistem yang mampu memberikan kemampuan pemecahan masalah maupun kemampuan pengkomunikasian untuk masalah dengan kondisi semi terstruktur dan tak terstruktur. Sistem ini digunakan untuk membantu pengambilan keputusan dalam situasi semi terstruktur dan situasi yang tidak terstruktur, dimana tak seorangpun tahu secara pasti bagaimana keputusan seharusnya dibuat.

Menurut Maryam Alavi dan H.Albert Napier, Sistem Pendukung Keputusan adalah suatu kumpulan prosedur pemprosesan data dan informasi yang berorientasi pada penggunaan model untuk menghasilkan berbagai jawaban yang dapat membantu manajemen dalam pengambilan keputusan. Sedangkan, Sprague dan Watson mendefinisikan Sistem Pendukung Keputusan (SPK) sebagai sistem yang memiliki lima karakteristik utama yaitu:

1. Sistem yang berbasis komputer.

2. Dipergunakan untuk membantu para pengambil keputusan

3. Untuk memecahkan masalah-masalah rumit yang mustahil dilakukan dengan kalkulasi manual

4. Melalui cara simulasi yang interaktif

5. Dimana data dan model analisis sebaai komponen utama[1].

SPK bertujuan untuk menyediakan informasi, membimbing, memberikan prediksi serta mengarahkan kepada pengguna informasi agar dapat melakukan pengambilan keputusan dengan lebih baik.

\subsection{Weighted Product (WP)}

Metode Weighted Product(WP) menggunakan perkalian untuk menghubungkan rating atribut, dimana rating setiapatribut harus dipangkatkan dulu dengan bobot atribut yang bersangkutan. Proses tersebut sama halnya dengan normalisasi. Metode Weighted Product dapat membantu dalam mengambil keputusan akan tetapi perhitungan dengan menggunakan metode weighted product ini hanya menghasilkan nilai terbesar yang akan terpilih sebagaialternatif yang terbaik[3].

Metode Weighted Product menggunakan perkalian untuk menghubungkan rating atribut, dimana rating setiap atribut harus dipangkatkan dulu dengan bobot atribut yang bersangkutan. Langkahlangkah dalam menggunakan metode ini adalah [3]:

1. Menentukan kriteria-kriteria yang akan dijadikan acuan dalam pengambilan keputusan.

2. Menentukan rating kecocokan setiap alternatif pada setiap kriteria.

3. Menentukan bobot preferensi tiap kriteria.

4. Mengalikan seluruh atribut bagi sebuah alternatif dengan bobot sebagai pangkat positif untuk atribut keuntungan dan bobot berpangkat negatif untuk atribut biaya

Preferensi untuk alternative $\mathrm{Si}$ diberikan sebagai berikut :

1. Penentuan nilai bobot $\mathrm{W}$

$$
W_{j}=\frac{W_{j}}{\sum w_{j}} \text {. }
$$

2. Menentuan nilai Vektor $S$

$$
S=\left(W_{i j}^{A W j} \cdot w\right) \cdot\left(W_{i n}^{A w n} \cdot w\right) \text {. }
$$

\section{Menentuan nilai Vektor V}

$$
V j n=\frac{s i}{\sum s i} \text {. }
$$

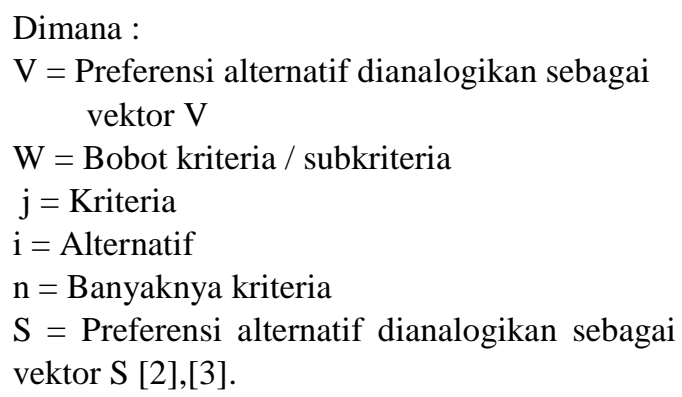

\subsection{PHP}

PHP adalah bahasa pemrograman yang sering disisipkan ke dalam HTML. PHP sendiri berasal dari kata Hypertext Preprocessor. Sejarah PHP pada awalnya merupakan kependekan dari Personal Home Page (Situs personal). PHP pertama kali dibuat oleh Rasmus Lerdorf pada tahun 1995. Pada waktu itu PHP masih bernama Form Interpreted (FI), yang wujudnya berupa sekumpulan skrip yang digunakan untuk mengolah data formulir dari web[4].

PHP disebut bahasa pemrograman server side karena PHP diproses pada komputer server. Hal ini berbeda dibandingkan dengan bahasa pemrograman client-side seperti JavaScript yang diproses pada web browser (client). Pada awalnya PHP merupakan singkatan dari Personal Home Page. Sesuai dengan namanya, PHP digunakan untuk membuat website pribadi. 


\subsection{MYSQL}

MySQL merupakan sebuah perangkat lunak atau software sistem manajemen basis data $S Q L$ atau DBMS Multithread dan multi user. MySQL sebenarnya merupakan turunan dari salah satu konsep utama dalam database untuk pemilihan atau seleksi dan pemasukan data yang memungkinkan pengoperasian data dikerjakan secara mudah dan otomatis. MySQL diciptakan oleh Michael "Monty" Widenius pada tahun 1979, seorang programmer komputer asal Swedia yang mengembangkan sebuah sistem database sederhana yang dinamakan UNIREG yang menggunakan koneksi low-level ISAM database engine dengan indexing[5].

$M y S Q L$ sebenarnya merupakan turunan salah satu konsep utama dalam database sejak lama, yaitu SQL (Structured Query Language). SQL adalah sebuah konsep pengoperasian database, terutama untuk pemilihan atau seleksi dan pemasukan data, yang memungkinkan pengoperasian data dikerjakan dengan mudah dan cepat secara otomatis. Keandalan suatu sistem database (DBMS) dapat diketahui dari cara kerja optimizer-nya dalam melakukan proses perintah-perintah SQL, yang dibuat oleh user maupun program-program aplikasinya. Sebagai database server, $M y S Q L$ dapat dikatakan lebih unggul dibandingkan database server lainnya dalam query data. Hal ini terbukti untuk query yang dilakukan oleh single user, kecepatan query MySQL bisa sepuluh kali lebih cepat dari PostgreSQL dan lima kali lebih cepat dibandingkan Interbase[6][7].

\section{HASIL DAN PEMBAHASAN}

\subsection{Perancangan Sistem}

Metode penelitian ini membuat tentang kerangka kerja penelitian yang berupa tahapantahapan yang harus dilalui selama melakukan penelitian. Adapun tahap-tahap dari sistem dapat dilihat dari flowchart dibawah ini:

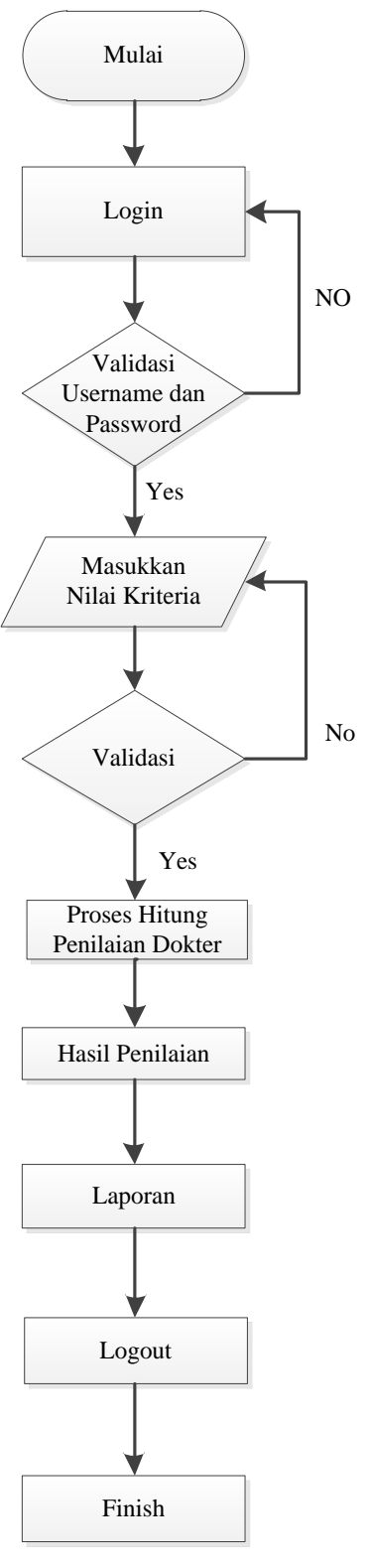

Gambar 1. Flowchart alur sistem

Selain flowchart, digunakan juga use case diagram untuk menerangkan proses-proses yang dilakukan user dalam menjalankan sistem. Use case diagram untuk user pada sistem pendukung keputusan dapat di lihat pada Gambar 2 berikut. 


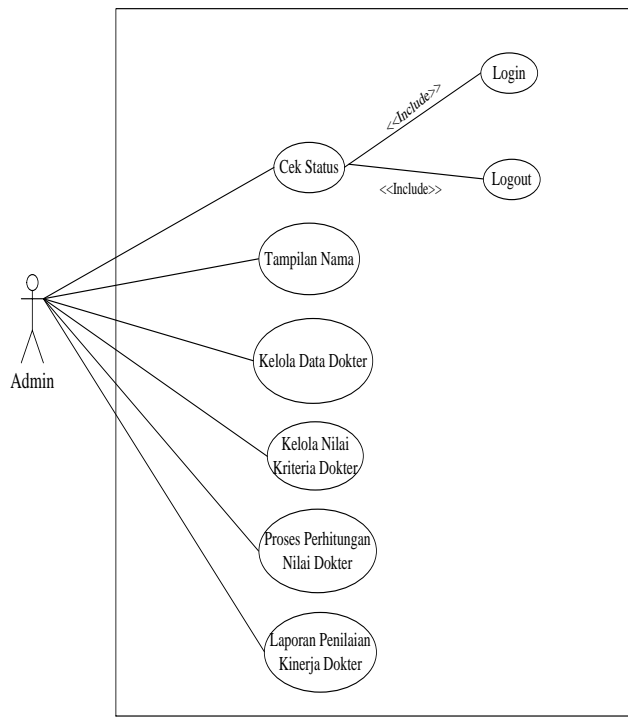

Gambar 2. Usecase Diagram SPK Penilaian Kinerja Dokter

\subsection{Hasil Dan Pembahasan}

Definisi masalah dan solusi yang diinginkan, dengan menentukan bobot nilai melalui pendekatan metode Weighted Product (WP). Kriteria , berikut ini adalah table bobot dari penilaian kinerja dokter RS Royal Prima Medan.

Tabel 1. Tebel Keterengan Nilai Bobotnya

\begin{tabular}{|l|l|l|l|}
\hline No. & $\begin{array}{l}\text { Skala } \\
\text { Penilaian }\end{array}$ & $\begin{array}{l}\text { Penilaian } \\
\text { Kriteria }\end{array}$ & Nilai Bobot \\
\hline 1. & $\begin{array}{l}\text { Sangat } \\
\text { kurang }\end{array}$ & $<50$ & 1 \\
\hline 2. & Kurang & $50-64$ & 2 \\
\hline 3. & Cukup & $65-74$ & 3 \\
\hline 4. & Baik & $75-84$ & 4 \\
\hline 5. & $\begin{array}{l}\text { Sangat } \\
\text { baik }\end{array}$ & $85-100$ & 5 \\
\hline
\end{tabular}

Tahapan analisis yang dilakukan berdasarkan langkah-langkah yang terdapat dalam metode Weighted Product (WP). Adapun langkah-langkah tersebut di antaranya sebagai berikut :

1. Menentukan kriteria pemilihan $(\mathrm{C} 1, \mathrm{C} 2 \ldots \mathrm{Cn})$. Kriteria dalam penelitian ini berfungsi sebagai variable input, sedangkan alternatif berfungsi sebagai variabel output.

Tabel 2. Tebel Skala Penilaian dan Keterengan Nilai Bobotnya

\begin{tabular}{|l|l|l|}
\hline No. & Nama Kriteria & Bobot \\
\hline C1 & Asuhan Pasien & 0,4 \\
\hline C2 & $\begin{array}{l}\text { Keterampilan } \\
\text { Interpersonal } \\
\text { Komunikasi }\end{array}$ & 0,1 \\
\hline C3 & $\begin{array}{l}\text { Penulisan \& Kelengkapan } \\
\text { Rekam Medis }\end{array}$ & 0,4 \\
\hline
\end{tabular}

\begin{tabular}{|l|l|l|}
\hline C4 & $\begin{array}{l}\text { Profesionalisme/ Perilaku } \\
\text { Kerja }\end{array}$ & 0,1 \\
\hline
\end{tabular}

2. Setelah ditentukan kriteria dan bobot, dicari kriteria mana yang bernilai keuntungan dan biaya. Jika bernilai keuntungan maka nilai atribut tersebut tetap (positif) dan jika bernilai biaya akan berubah menjadi negatif. Pada contoh kasus diatas semua atribut bernilai positif.

3. Setelah mendapatkan nilai bobot pada masingmasing kriteria maka dilakukan Perbaikan Bobot dari Nilai bobot awal dengan rumus :

$$
\begin{aligned}
& W_{j}=\frac{W_{j}}{\sum W_{j}} \\
& W 1=\frac{0,4}{0,4+0,1+0,4+0,1}=0,4 \\
& W 2=\frac{0,1}{0,4+0,1+0,4+0,1}=0,1 \\
& W 3=\frac{0,4}{0,4+0,1+0,4+0,1}=0,4 \\
& W 4=\frac{0,1}{0,4+0,1+0,4+0,1}=0,1
\end{aligned}
$$

4. Setelah dilakukan perbaikan bobot dilakukan perhitungan nilai vektor $(\mathrm{S})$.

Tabel 3. Data Penilaian

\begin{tabular}{|l|l|l|l|l|}
\hline \multirow{2}{*}{$\begin{array}{l}\text { Altermatif } \\
\text { (Sampel) }\end{array}$} & \multicolumn{4}{|l|}{ Kriteria } \\
\cline { 2 - 5 } & C1 & C2 & C3 & C4 \\
\hline S1 & 85 & 86 & 80 & 87 \\
\hline S2 & 90 & 76 & 72 & 86 \\
\hline S3 & 84 & 73 & 77 & 82 \\
\hline S4 & 87 & 83 & 89 & 91 \\
\hline S5 & 93 & 74 & 87 & 80 \\
\hline
\end{tabular}

Tabel 4. Perubahan Nilai Bobot Kriteria

\begin{tabular}{|l|l|l|l|l|}
\hline \multirow{2}{*}{ Sampel } & \multicolumn{4}{|l|}{ Kriteria } \\
\cline { 2 - 5 } & C1 & C2 & C3 & C4 \\
\hline S1 & 5 & 5 & 4 & 5 \\
\hline S2 & 5 & 4 & 3 & 5 \\
\hline S3 & 4 & 3 & 4 & 4 \\
\hline S4 & 5 & 4 & 5 & 5 \\
\hline S5 & 5 & 3 & 5 & 4 \\
\hline
\end{tabular}

5. Menghitung Nilai Vektor $S$

Untuk menghitung nilai Vektor $S$ adalah nilai di pangkatkan dengan total bobot untuk masingmasing nilai kriteria. Dengan menggunakan rumus sebagai berikut

$$
\begin{aligned}
s & =\left(W_{i j}^{A W j} \cdot w\right) \cdot\left(W_{i n}^{A w n} \cdot w\right) \\
s_{1} & =\left(5^{0,4}\right)\left(5^{0,1}\right)\left(4^{0,4}\right)\left(5^{0,1}\right)=4,5727 \\
s_{2} & =\left(5^{0,4}\right)\left(4^{0,1}\right)\left(3^{0,4}\right)\left(5^{0,1}\right)=3,9853 \\
s_{1} & =\left(4^{0,4}\right)\left(3^{0,1}\right)\left(4^{0,4}\right)\left(4^{0,1}\right)=3,8861 \\
s_{4} & =\left(5^{0,4}\right)\left(4^{0,1}\right)\left(5^{0,4}\right)\left(5^{0,1}\right)=4,8888 \\
s_{5} & =\left(5^{0,4}\right)\left(3^{0,1}\right)\left(5^{0,4}\right)\left(4^{0,1}\right)=4,6454
\end{aligned}
$$


6. Setelah mendapatkan nilai Vektor (S) langkah selanjutnya yaitu menentukan Nilai vector (V). Formula yang dilakukan seperti berikut:

$$
\begin{aligned}
& V j n=\frac{S i}{\sum S i} \\
& \mathrm{~V} 1=\frac{4,5727}{21,978 a}=0,2080 \\
& \mathrm{~V} 2=\frac{3,985 a}{21,978 a}=0,1813 \\
& \mathrm{~V} 3=\frac{3,9861}{21,979 a}=0,1768 \\
& \mathrm{~V} 4=\frac{4,8898}{21,978 a}=0,2224 \\
& \mathrm{~V} 5=\frac{4,6454}{21,9783}=0,2113
\end{aligned}
$$

7. Setelah mendapatkan nilai Vektor V maka langkah selanjutnya mengurutkan nilai Vektor V dari urutan terbesar ke urutan terkecil.

Tabel 5. Hasil Perangkingan

\begin{tabular}{|l|l|l|l|}
\hline Sampel & $\begin{array}{l}\text { Nilai } \\
\text { Vektor S }\end{array}$ & $\begin{array}{l}\text { Nilai } \\
\text { Vektor } \\
\text { V }\end{array}$ & Ranking \\
\hline S1 & 4,5727 & 0,2080 & 3 \\
\hline S2 & 3,9853 & 0,1813 & 4 \\
\hline S3 & 3,8861 & 0,1768 & 5 \\
\hline S4 & 4,8888 & 0,2224 & 1 \\
\hline S5 & 4,6454 & 0,2113 & 2 \\
\hline
\end{tabular}

Dari hasil perangkingan pada tabel 3.5 di atas dapat diambil sebuah keputusan bahwa Alternatif yang terbaik adalah $\mathrm{S} 4$ dengan nilai 0,2224 .

\subsection{Rancangan User Interface}

Berikut ini adalah gambaran hasil dari sistem yang telah dirancang, yaitu sebagai berikut:

\subsubsection{Tampilan Login}

Tampilan login hanya dapat digunakan oleh admin dalam mengelola sitem. Tampilan login bisa dilihat dari Gambar 3 dibawah ini.

\begin{tabular}{l|l|}
\hline Login Admin \\
\hline Email or Username \\
\hline Password \\
\hline \\
Lupa Password \\
Daftar Akun Baru \\
\hline
\end{tabular}

Gambar 3. Login

\subsubsection{Tampilan Utama}

Setelah login admin akan masuk ke tampilan menu utama. Menu utama ini berisikan data dari tabel penilaian kriteria dan bobot.

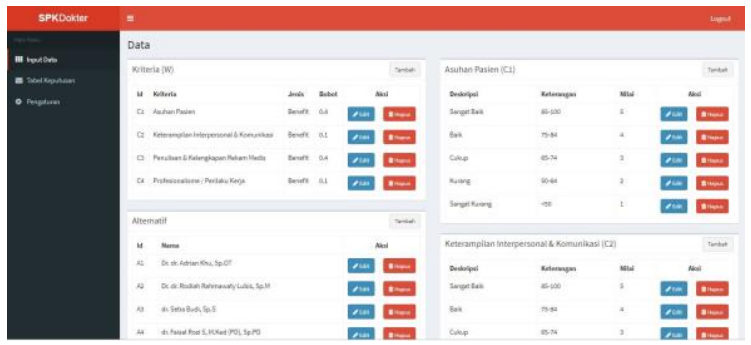

Gambar 4. Tampilan Menu Utama

\subsubsection{Tabel Pencocokan}

Setelah nama dokter di input tahap selanjutnya diberi penilaian di setiap kriterianya. Terdapat pada gambar dibawah ini.

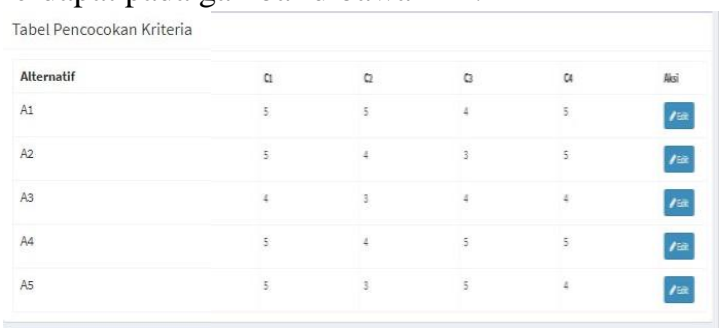

Gambar 5. Tabel Pencocokan Kriteria

\subsubsection{Hasil Penilaian}

Hasil daari perhitungan dapat dilihat dari besarnya hasil yang didapat. Seperti contoh Gambar 5 dibawah ini. Hasil perhitungan menggunakan metode WP. Alternatif terbaik adalah A4 yaitu dengan nilai 4.8896 .

\section{Nilai S}

\begin{tabular}{l|l} 
Alternatif & \multicolumn{1}{l}{ Nilai S } \\
\hline A1 & 4.5730505192733 \\
\hline A2 & 3.9860202728702 \\
\hline A3 & 3.8865666314523 \\
\hline A4 & 4.8896638427146 \\
\hline A5 & 4.6461596419874 \\
\hline
\end{tabular}

Gambar 6. Hasil Penilaian

\section{KESIMPULAN}

Berdasarkan hasil rancangan dari Sistem Pendukung Keputusan Penilaian Kinerja Dokter dengan menggunakan metode Weight Product maka dapat disimpulkan sebagai berikut:

1. Dokter yang mendapatkan penilaian tertinggi adalah dengan sampel S4, yaitu dengan nilai 4.8896 Nilai V 0.2224 .

2. Dengan menggunakan sistem terkomputerisasi dalam pencarian penilaian 
kinerja dokter lebih cepat, tepat dan penilaian sangat akurat.

3. Dengan adanya database, data yang sudah dimasukkan apabila terjadi masalah tidak perlu menginput ulang data, cukup dengan mengubah data di database.

\section{DAFTAR PUSTAKA}

[1] Fitri Nana Yulia. Nurhadi."Analisis Dan Perancangan Sistem Pendukung Keputusan Penilaian Kinerja Guru Dengan Menggunakan Metode Simple Additive Weighting (Saw) Pada SMK Yadika Jambi”. Jurnal Manajemen Sistem Informasi, Vol.2, No.1. 2017.

[2] Mukmin Muhammad, L.M., Jabal Nur, Dkk. "Sistem Pendukung Keputusan Untuk Penentuan Mahasiswa Berprestasi Menggunakan Weighted Product (Wp)". Jurnal Informatika, Volume 9 Nomor 1. 2018.

[3] Izzah Nailul, Ardianik. “ Sistem Pendukung Keputusan Pemilihan Supplier Obat Menggunakan Metode Weighted Product". Jurnal Ilmiah Matematika Dan Pendidikan Matematika, Volume 8, Nomor 2. 2018.

[4] Nagara Erliza Septia, Rini Nurhayati. "Sistem Pendukung Keputusan Penentuan Hama Padi Menggunakan Php”. Jurnal Tam (Technology Acceptance Model), Volume 4. 2015.

[5] Faisal Muhammad. " Implementasi Metode Topsis Dalam Sistem Pendukung Keputusan Seleksi Penerima Beasiswa Bidikmisi Berbasis Web". Citec Journal, Vol. 3, No. 4. 2016.

[6] Pandean Santo Sinar. Seng Hansun. "Aplikasi Web Untuk Rekomendasi Restoran Menggunakan Weighted Product". Jurnal Teknologi Informasi Dan Ilmu Komputer (Jtiik), Vol. 5, No. 1, Maret 2018, Hlm. 87-94. 2017.

[7] Ricon Irfandi, Rini Sovia,Dkk."Perancangan Aplikasi Sistem Pengambilan Keputusan Dalam Penerimaan Anggota Baru Pada Ukm It Cybernetix Menggunakan Metode Analytic Hierarchy Process Dengan Bahasa Pemrograman Php \& Mysql" Jurnal Inkofar , Volume 1 No. 1. 2017.

[8] E. Indra and B. Jaya, "Sistem Pendukung Keputusan Untuk Menentukan E-Commerce Yang Banyak Diminati Dengan Metode Saw,"
SNITIK [Prosiding Seminar. Nasional. Inovasi. Teknologi. dan Ilmu Komputer., 2018. 